\title{
Diver Sidade
}

\section{MARIA, CARLOS E O PROJETO DE EDUCAÇÃO PARA A SEXUALIDADE}

\author{
Juliana Lapa Rizza ${ }^{1}$ \\ Cristina Monteggia Varela ${ }^{2}$
}

Olá, pessoal!!! Tudo bem com vocês?

Comigo, tudo ótimo! Já estava com saudades de escrever aqui, neste espaço da revista, e dividir com vocês um pouco das minhas histórias. Têm acontecido tantas coisas, tenho muitas novidades para contar. Lá na escola, eu e meus amigos e amigas temos feito muitos trabalhos e continuamos com o Projeto de Educação para a Sexualidade, diferente da escola do meu irmão Carlos. Ele sempre me contava que as coisas de meninos e meninas eram bem separadas, acho que lá, as professoras, os professores e as crianças não falavam muito sobre gênero e sexualidade, como na minha escola.

Vocês conhecem o meu irmão Carlos? Já contei tantas coisas para vocês, que não lembro bem se já falei dele aqui nas histórias que divido com vocês.

Carlos é um pouco mais novo do que eu, ele ainda estuda na Educação Infantil, somos melhores amigos e fazemos quase tudo juntos. Brincamos, fazemos aula de balé e neste ano entramos para a capoeira também!

\footnotetext{
${ }^{1}$ Possui graduação em Pedagogia Licenciatura com Habilitação nos Anos Iniciais pela Universidade Federal do Rio Grande - FURG, Mestrado em Educação Ambiental pela FURG e Doutorado também em Educação Ambiental pela FURG. Realiza Pós-Doutorado no PPG Educação em Ciências, associação ampla FURG-UFRGS-UFSM. Pesquisadora integrante do Grupo de Pesquisa Sexualidade e Escola GESE/FURG.

${ }^{2}$ Formada no Curso de Pedagogia com Habilitação em Anos Iniciais e Educação Infantil pela Universidade do Estado de Santa Catarina (UDESC). Mestre em Educação pelo Programa de PósGraduação em Educação (PPGE), do Centro de Ciências Humanas e da Educação (FAED), da Universidade do Estado de Santa Catarina (UDESC), na linha Educação, Comunicação e Tecnologia. Doutoranda do Programa de Pós-Graduação em Educação em Ciências: Química da Vida e Saúde, pela Universidade Federal do Rio Grande - FURG. Pesquisadora integrante do Grupo de Pesquisa Sexualidade e Escola - GESE e do Grupo de Pesquisa EDUSEX Formação de Educadores e Educação Sexual $\mathrm{CNPq} / \mathrm{UDESC}$.
} 
Como eu disse pra vocês, lá na escola do Carlos não tinha Projeto de Educação para a Sexualidade como na minha escola, então meu irmão estava passando por momentos complicados com alguns colegas por causa de preconceito. É gente, criança pequena também tem preconceito e muitas vezes, pode ser bem maldosa nos comentários para os amigos e as amigas. A turma do Carlos não aceitava que ele podia fazer balé por ser menino. Como pode isso? Se a turma do colégio do Carlos fosse na nossa escola de balé veria que muitos meninos fazem balé, afinal é só uma dança. E mais ou menos essa foi a ideia que tive para ajudar o Carlos!

Por gostar de balé e de fazer aula, houveram muitos momentos em que Carlos foi xingado por seus amigos e suas amigas, diziam que balé é coisa de menininha. Até que teve um dia em que Carlos cansou e decidiu parar de fazer balé para não sofrer mais. Mas como eu e meus pais poderíamos deixar que Carlos desistisse de algo que gosta tanto por causa de preconceito?

Contei essa história do preconceito que o Carlos estava sofrendo na escola dele para o profe Rogério e para a nossa super diretora, a profe Fafá, e juntos bolamos um plano para ajudar a profe do Carlos e a escola dele a enfrentarem esse problema.

Todo nosso plano começou no dia do Show de Talentos lá da escola. Esse show acontece junto com a festa da família, e é um momento em que todas as crianças e suas famílias podem se apresentar juntas mostrando seus talentos.

Convidei os amigos e amigas do Carlos para virem nos assistir no Show de Talentos, em que apresentamos uma dança de balé... e funcionou, pois desde aquele dia, a profe do Carlos começou a estudar e conversar com pessoas que entendem o que é a educação para a sexualidade e porque é tão importante que ela aconteça nas escolas para que tenhamos relações de amizade e respeito às diferenças, sem preconceito, violência ou discriminação.

A profe do Carlos começou o Projeto de Educação para a Sexualidade falando sobre o balé, para que a turma pudesse conhecer mais sobre essa dança, estudando um pouco de sua história.

Todos os dias, o Carlos chega em casa super empolgado com alguma novidade. Hoje ele veio falante por todo o caminho da escola até em casa, contando o que havia aprendido e assim que entramos em casa já foi falando tudo de novo para a nossa mãe:

- Manhêêê, hoje eu aprendi muitas coisas sobre balé na escola. Vindo pra casa, contei pra Maria e pro papai que foram os homens que criaram o balé. Eu e minha turma 
vimos em um livro de história com a profe, que há muito tempo atrás só os homens podiam dançar.

- Isso mesmo, Carlos, saber dançar significava que a pessoa tinha boa educação e fazia parte de uma família rica, completou o pai.

- A profe Débora, lá da nossa escola de balé, Carlos, comentou que as meninas só começaram a dançar bem depois dos homens. E o balé para as meninas era uma forma de educá-las para que sentassem, caminhassem e se comportassem da forma correta. Eu comentei.

- Quantas coisas legais aprendeste na escola, Carlos. Agora teus colegas puderam conhecer um pouco sobre o balé, e que essa é uma dança que meninos e meninas podem fazer. Falou minha mãe.

O Carlos ficou tão feliz com o que aprendeu. Ele disse que agora alguns colegas até estavam brincando de balé com ele e que a profe disse que vai levar toda a turma lá na escola de balé da profe Débora para fazerem uma aula, todo mundo junto.

As novidades que Carlos trazia de sua escola sobre o balé continuaram chegando. Foram tantas as descobertas e atividades que eu até fiquei com vontade de ser aluna da escola do Carlos também para poder participar do projeto.

No dia do passeio da turma dele à escola de balé, foi exatamente no dia que eu estava participando de um ensaio geral com minha turma para nossa apresentação de final de ano.

Eu acho que estava tão ansiosa quanto o Carlos para receber os colegas dele na escola de balé. A profe Débora preparou várias atividades e histórias para contar e no final da tarde, teríamos um grande lanche coletivo para que todas as crianças pudessem se conhecer.

Durante a tarde, quando tive um intervalo no meu ensaio, fui espiar como estavam Carlos e seus amigos e amigas. Acho que a história estava muito boa, pois ninguém piscava e a profe Débora ia contando histórias sobre o balé ao longo dos anos, misturando passos de dança, músicas, coreografia e brincadeiras. Parecia tudo muito mágico!

A história da profe Débora dizia como os papéis principais nas grandes apresentações de balé eram destinados aos homens, pois, devido a seu figurino, tinham muito mais mobilidade para desenvolver passos elaborados e saltos. As mulheres, naquela época, século XVIII, usam vestidos muito longos e rodados, além de sapatilhas 
com saltos altos que dificultavam seus movimentos, por isso não tinham as mesmas possibilidades na dança do que os homens.

Vejam só, foi uma mulher belga, Marie Ann Cupis de Camargo quem iniciou o processo de revolucionar tais normas impostas às mulheres bailarinas, diminuindo o salto da sapatilha e diminuindo o comprimento do vestido.

$\mathrm{Eu}$ achei essa história fantástica. Fiquei me perguntando como tudo muda durante os anos. Hoje temos muito preconceito com relação a homens e meninos fazendo balé, como se essa fosse uma dança só de meninas. Mas não faz tanto tempo assim, apenas 400 anos atrás, éramos nós, mulheres e meninas, que lutávamos pelo nosso espaço para fazer balé, como o Carlos tem feito na escola dele. Por isso que o profe Rogério sempre diz que o que dizemos ser de meninas e de meninos são construções históricas, que algum dia já foram diferentes, e que hoje podemos fazê-las mudarem!

Ao final das atividades de nossa tarde, nos reunimos todos e todas, alunos e alunas da escola de balé e a turma do Carlos e sua professora no grande lanche coletivo. Estávamos muito animados conversando, fazendo milhares de perguntas e contando sobre as descobertas da tarde.

Aproveitei esse momento para conversar com Carlos sobre o passeio e perguntar o que ele estava achando do dia.

- Nossa, Maria, quanta coisa que a profe Débora nos contou hoje. Foi muita surpresa descobrir como demorou para inventarem a dança na ponta do pé. Parecia que sempre tinha existido tudo isso. A história é tão legal, né? Descobrir sobre o mundo e como tudo está sempre mudando.

- Realmente, Carlos, a história nos ajuda a entender as coisas e a mudar as coisas também.

- Sabe, Maria, só fiquei chateado com um comentário do meu amigo Dudu, ele disse que menino pode até dançar balé, mas nada de usar collant e meia calça. Acho que ele não está entendendo muitas coisas.

- Ah, Carlos, demora. Quem sabe depois da história do balé você e sua turma não pedem a sua profe para estudar sobre as roupas e conhecer mais sobre elas. Pode ajudar seu amigo Dudu a entender que não precisa existir roupas de meninos e meninas, mas apenas roupas.

Carlos ficou pensando no que eu disse e saiu correndo para contar a profe essa ideia de pesquisar sobre as roupas e quem inventou essa ideia de roupas de meninos e 
meninas. A história não termina aqui, porque o Carlos vai continuar o projeto na escola e eu, minha turma e o profe Rogério também vamos continuar conversando sobre as cores, roupas, brinquedos, jogos, brincadeiras de meninos e meninas.

Tenho certeza que muitas outras histórias ainda vão poder ser contadas, já que o Projeto de Educação para a Sexualidade na minha escola vai continuar e agora na escola do Carlos, pelo visto, a profe também vai começar a conversar com as crianças sobre as questões de gênero e sexualidade. Com esse projeto lá na escola aprendi tantas novidades, minha turma e eu pudemos pensar sobre preconceito, as diferenças, brinquedos, cores e brincadeiras que vão nos sendo ensinado como sendo de menino e menina. Espero que assim como na minha escola e na escola do Carlos, outras professoras e professores possam conversar com as crianças sobre essas questões para que elas possam ser felizes e viverem sem preconceitos. 